\begin{tabular}{|c|c|c|}
\hline \hline & International Journal of Current Research in \\
\hline & Biosciences and Plant Biology \\
\hline EXCELLENT \\
PUBLISHERS
\end{tabular}

\title{
Response of lactating Zaraibi goats fed with berseem and/or triticale forage on milk production, feed utilization and economic efficiency
}

\author{
M. E. El-Kholany, W.M.A. Sadek*, M. A. Aboul-Omran, H. R. Behery, \\ G.I. El-Emam, T.H. El-Sawah, A.A. Mehany and Ayman Al-Mwafy
}

Animal Production Research Institute, Agriculture Research Center, Ministry of Agriculture, Cairo, Egypt

${ }^{*}$ Corresponding author

\begin{tabular}{|c|c|}
\hline Article Info & ABSTRACT \\
\hline $\begin{array}{l}\text { Date of Acceptance: } \\
15 \text { February } 2019\end{array}$ & \multirow{3}{*}{ 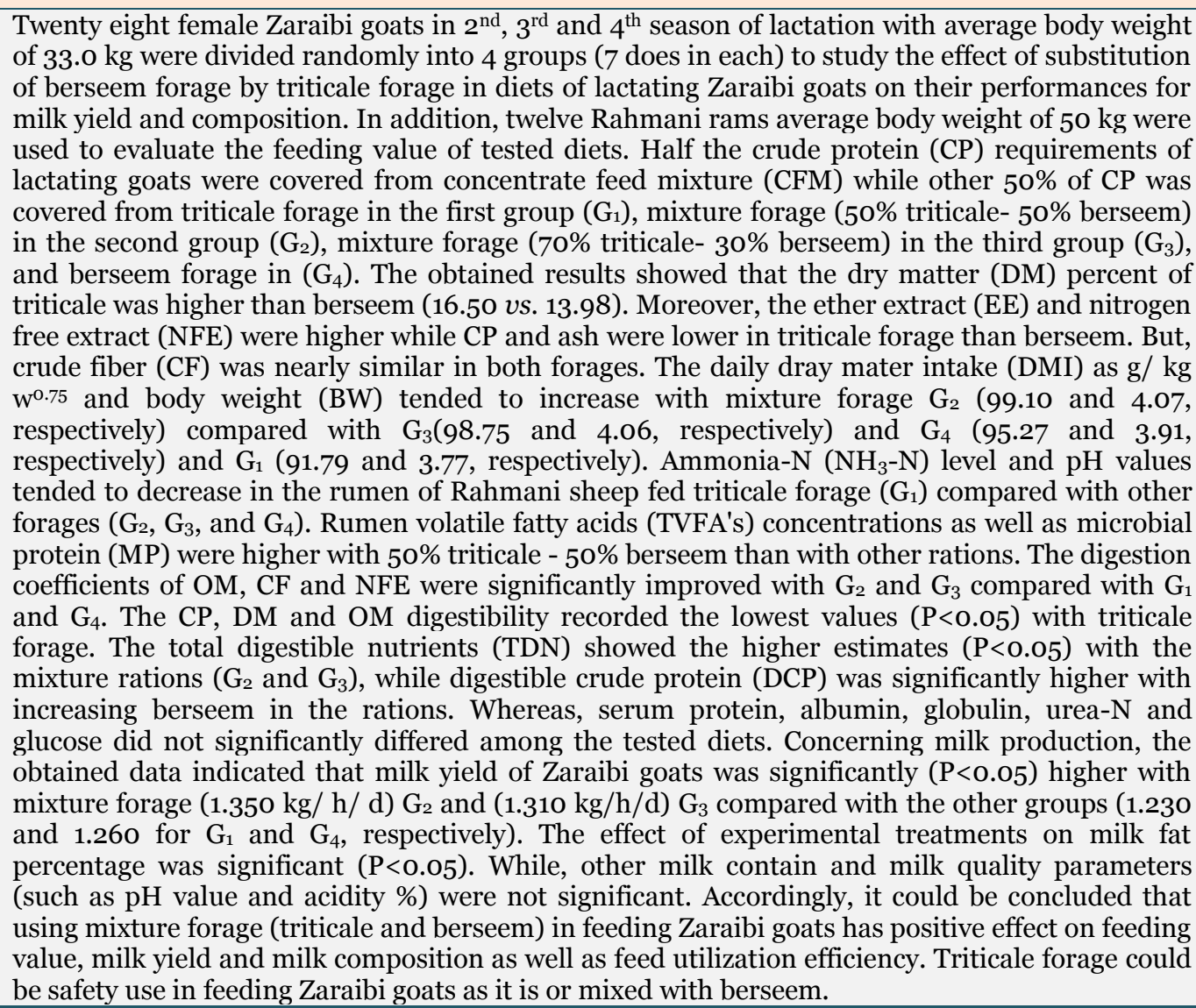 } \\
\hline Keywords & \\
\hline $\begin{array}{l}\text { Blood parameters } \\
\text { Economical efficiency } \\
\text { Feeding value } \\
\text { Milk production } \\
\text { Rumen parameters } \\
\text { Triticale forage } \\
\text { Zaraibi goats }\end{array}$ & \\
\hline
\end{tabular}




\section{Introduction}

Triticale is a relatively new cereal crop could be used simultaneously for forage and grain product, it could be grazed one or two times during the early stages of growth (prior to joining) and later to allow to produce grain yield Garico Delmoral (1992). Even though, triticale was developed as a food grain, it has more potential as a feed for farm animals Hill and Utley (1989) and Zobell et al. (1992). In a recent study, Abdel-Galil and Soliman (2002) concluded that the obtained data suggested that, although triticale (as the first man-made cereal) was produced mainly as a cereal crop it could be used as a double purpose crop, giving the grower the alternatives to have either green forage only or green forage plus grain yield. When triticale used as forage crop, it has been found to have higher forage potential and protein content than oats and higher forage and silage yields than wheat, rye and barley Varughese et al. (1987). In another study on Rahmani rams, Haggag et al. (2002) observed that the digestion coefficients of most nutrients and feeding values were better than with rations mixed with berseem than both triticale or berseem forage alone.

Therefore, this work was aimed to using of triticale forage in feeding small ruminants to determine it's effect on digestibility, feeding values, some blood and rumen parameters and economical efficiency.

\section{Materials and methods}

This study was conducted at El-Serw Experimental Research Station belongs to Animal Production Research Institute, Agricultural Research Center, Ministry of Agriculture, Egypt. Zaraibi does, averaged $35.0 \mathrm{~kg}$ live body weight, were divided into three feeding treatments ( 7 does each). The experiments began two weeks after weaning (during mid-lactation) and until the seventh month of lactation (at mating). Each group was housed in a semi-roofed barn $(4 \times 3 \times 5$ meters $)$. Animals were weighed at the beginning of the experimental and biweekly. All groups were fed on restricted amount of concentrate feed mixture $(\mathrm{CFM})$, to cover $50 \%$ of the requirements recommended by NRC (1981) for lactating goats. Yet, a combination of different forages was fed ad-libitum. Accordingly rations tested were, $\mathrm{CFM}+100 \%$ triticale $\left(\mathrm{G}_{1}\right), \mathrm{CFM}+50 \%$ triticale +
$50 \%$ berseem $\left(\mathrm{G}_{2}\right), \mathrm{CFM}+70 \%$ triticale $+30 \%$ berseem $\left(\mathrm{G}_{3}\right)$ and CFM $+100 \%$ berseem $\left(\mathrm{G}_{4}\right)$.

The triticale and berseem were cultivated in El-Serw Experimental Stations. Triticale and berseem were obtained from the $3^{\text {rd }}$ cut. Concentrate feed mixture (CFM) contained, undecortecated cotton meal (25\%), yellow corn (43\%), wheat bran (25\%), molasses (3.5\%), Limestone (2\%), common salt (1.0\%) and minerals mixture (0.5\%). The chemical composition was estimated for the tested ingredients are shown in Table 1. Water was available all times. Diets were offered twice daily at 8.0 am and $3 \mathrm{pm}$.

Ruminal fluid samples were taken from rams using stomach tube before feeding (o time) and at 2, 4 and $6 \mathrm{hrs}$ post-feeding at the end of digestibility trails. The samples were filtered through 3 layers of gauze and directed to the determination of $\mathrm{pH}$ value. Ammonia nitrogen $\left(\mathrm{NH}_{3}-\mathrm{N}\right)$ concentration was measured according to Conway (1957) method whereas total volatile fatty acids (VFA's) according to the technique by Warner (1964); and microbial protein level was estimated by the methods of Shultz and Shultz (1970).

Milk yield was recorded daily for each doe. Representative milk samples (about $0.5 \%$ of the total milk produced) were taken biweekly for each doe at both milking. Samples were composed and analyzed for chemical composition of total solids, fat. Protein and ash as well as $\mathrm{pH}$ and acidity (Ling, 1963); while lactose content was assessed as described by Barnett and Abdel-Tawab (1957).

Blood plasma was separated by centrifugation at $4000 \mathrm{rpm}$ for 10 minutes, then frozen at $-20^{\circ} \mathrm{c}$ until analysis for total protein (TP), albumin (AL), urea-N, glucose and creatinine using kits and the methods reported by Biochemistry (Biomerieux) laboratory reagents and products. Serum total globulin (GL) was calculated by differences (TP$\mathrm{AL})$.

In addition, four digestibility trails were conducted using rams to evaluate the nutritive values of the tested diets. Samples of feed and feces were analyzed according to A.O.A.C. (1995).

Data were statistically analyzed using SAS (2003). The significant differences among were assigned according to Duncan (1955). 


\section{Results and discussion}

\section{Chemical composition of forages}

The chemical composition of feed ingredients is presented in Table 1. The dry matter of triticale was higher than berseem (16.50\% vs. 13.85\%). Moreover, the EE and NFE were higher while CP and ash were lower in triticale forage than berseem. But, CF was nearly similar in both forages as shown in Table 1. Nearly similar chemical composition was obtained by Haggag et al. (2002) who reported that triticale forage contented $10.90 \% \mathrm{CP}, 2.60 \mathrm{EE}, 29.80 \% \mathrm{CF}$, 46.94\% NFE and 9.25\% ash. In this respect, Gabra and Sherif (1985) founded that triticale contained $10.75 \% \mathrm{CP}, 2.86 \% \mathrm{EE}, 28.65 \% \mathrm{CF}$ and $43.62 \%$ NFE, but ash was higher than that obtained herein (14.12 vs. 8.70\%). Abdel-Galil and Soliman (2002) studied chemical composition of 5 triticale species and observed that ash content ranged from 7.6 to $9.6 \%$ in the $3^{\text {rd }}$ cut of triticale, while it ranged from 15.6 to $16.8 \%$ and from 10.4 to $11.8 \%$ in the first and second cut, respectively.

Table 1. Chemical analysis \% (on dry matter basis) of tested rations.

\begin{tabular}{llllllll}
\hline \multirow{2}{*}{ Feed mixture } & \multirow{2}{*}{ DM } & \multicolumn{2}{c}{ Chemical analysis\% (on DM basis) } & & \\
\cline { 3 - 8 } & & OM & CF & CP & EE & NFE & Ash \\
\hline Concentrate feed mixture $(\mathrm{CFM})$ & 91.5 & 93.85 & 15.80 & 14.30 & 3.20 & 60.55 & 6.15 \\
100\% triticale $\left(\mathrm{G}_{1}\right)$ & 16.50 & 91.30 & 29.80 & 10.80 & 2.55 & 48.15 & 8.70 \\
$50 \%$ triticale $+50 \%$ berseem $\left(\mathrm{G}_{2}\right)$ & 14.90 & 90.35 & 28.30 & 12.25 & 2.35 & 47.45 & 9.65 \\
70\% triticale $+30 \%$ berseem $\left(\mathrm{G}_{3}\right)$ & 15.40 & 90.85 & 28.90 & 11.65 & 2.42 & 47.88 & 9.15 \\
$100 \%$ berseem $\left(\mathrm{G}_{4}\right)$ & 13.85 & 87.95 & 28.95 & 14.15 & 1.95 & 42.90 & 12.05 \\
\hline
\end{tabular}

\section{Feed intake and water consumption}

The average daily feed intake of lactating Zaraibi goats is summarized in Table 2. The total DM intake as $(\mathrm{g} / \mathrm{h} / \mathrm{d})$ or $\left(\mathrm{g} / \mathrm{kgw}^{0.75}\right)$ tended to increase with $\mathrm{G}_{2}$ and $\mathrm{G}_{3}$ (mixture forages) compared to $\mathrm{G}_{1}$ (triticale) and $\mathrm{G}_{4}$ (berseem). The differences between $G_{1}$, triticale and $G_{4}$ (berseem) were not significant. Similarly results were reported by Gabra and Sherif (1995) who noticed that daily feed intake was significantly higher with sheep fed mixture forage (50\% triticale- $50 \%$ berseem) than fed triticale or berseem forage alone. Similar results were observed by Shehata et al. (2001), Ahmed et al. (2001) and Ibrahim et al., (2012) with using of mixture silages in small ruminants rations.

Concerning water consumption, does consumed the least amount of water when fed on mixture forage $(4.01 \mathrm{l} / \mathrm{h} / \mathrm{d}$ or $278 \mathrm{ml} / \mathrm{kg} \mathrm{w} 0.75)$ while recorded the highest consumption when fed triticale forage $(4.27 \mathrm{l} / \mathrm{h} / \mathrm{d}$ or $296 \mathrm{ml} / \mathrm{kg} \mathrm{w} 0.75)$ as shown in Table 2.

Table 2. Average daily feed intake and water consumption by lactating goats fed the experimental rations.

\begin{tabular}{|c|c|c|c|c|}
\hline \multirow{2}{*}{ Parameters } & \multicolumn{4}{|l|}{ Groups } \\
\hline & $\mathbf{G}_{\mathbf{1}}$ & $\mathbf{G}_{\mathbf{2}}$ & $\mathbf{G}_{3}$ & $\mathbf{G}_{4}$ \\
\hline \multicolumn{5}{|c|}{ Daily DM intake (g/h) during experimental period } \\
\hline $\mathrm{CFM}$ & 650 & 660 & 665 & 640 \\
\hline Forages & 720 & 765 & 755 & 680 \\
\hline Total DM intake & 1370 & 1425 & 1420 & 1320 \\
\hline DM intake, \% of BW & $3 \cdot 90^{\mathrm{b}}$ & $4.07^{\mathrm{a}}$ & $4.06^{\mathrm{a}}$ & $3.77^{\mathrm{b}}$ \\
\hline DM intake, $\mathrm{g} / \mathrm{kg} \mathrm{w} 0.75$ & $95.27^{b}$ & $99.10^{\mathrm{a}}$ & $98.75^{\mathrm{a}}$ & $91.79^{b}$ \\
\hline Roughage: concentrate $\mathrm{R} / \mathrm{C}$ ratio & $52.55: 47.45$ & $53.70: 46.30$ & $53.17: 46.83$ & $51.50: 48.50$ \\
\hline \multicolumn{5}{|l|}{ Daily water consumption } \\
\hline L/ head/ day & 4.27 & 4.01 & 4.23 & 4.15 \\
\hline $\mathrm{Ml} / \mathrm{kg} \mathrm{BW}$ & 122 & 115 & 120 & 118 \\
\hline $\mathrm{Ml} / \mathrm{kg} \mathrm{w}^{0.75}$ & 296 & 278 & 294 & 288 \\
\hline $\mathrm{Ml} / \mathrm{g} \mathrm{DM}$ intake & 3.11 & 2.80 & 2.97 & 3.14 \\
\hline
\end{tabular}

a-b: Means in the same row followed by different letters differ significantly at $(\mathrm{P}<0.05)$. 


\section{Ruminal fermentation parameters}

The $\mathrm{pH}$ values, ammonia-N $\left(\mathrm{NH}_{3}-\mathrm{N}\right)$, total volatile fatty acids (TVFA's) and microbial protein in the rumen of sheep were presented in Table 3. Both ammonia- $\mathrm{N}$ and $\mathrm{pH}$ values were tended decreased with increasing triticale in sheep rations. Ammonia-N concentration (after feeding) was higher by about $7.14 \%$ with berseem rations $\left(\mathrm{G}_{4}\right)$ compared with triticale forage $\left(\mathrm{G}_{1}\right)$ but the differences were not significant. Moreover, ruminal ammonia-N concentration was greatly higher post-feeding than before feeding and that maximum values of $\mathrm{NH}_{3}-\mathrm{N}$ in the rumen were reached at $4 \mathrm{hrs}$ post-feeding then decreased with all dietary treatments. Similar results were observed by Ahmed (1999) and Zeid et al. (2009).

Table 3. Rumen fermentation parameters of Rahmani sheep fed the experimental rations contained triticale and/or berseem.

\begin{tabular}{|c|c|c|c|c|c|}
\hline \multirow{2}{*}{ Parameters } & \multirow{2}{*}{ Hrs. } & \multicolumn{4}{|l|}{ Groups } \\
\hline & & $\mathbf{G}_{\mathbf{1}}$ & $\mathbf{G}_{2}$ & $\mathbf{G}_{\mathbf{3}}$ & $\mathbf{G}_{4}$ \\
\hline \multirow[t]{4}{*}{$\mathrm{pH}$ value } & 0 & $6.92 \pm 0.09$ & $6.96 \pm 0.09$ & $7.0 \pm 0.11$ & $7.06 \pm 0.09$ \\
\hline & 2 & $6.45 \pm 0.05$ & $6.60 \pm 0.04$ & $6.56 \pm 0.03$ & $6.65 \pm 0.05$ \\
\hline & 4 & $6.31 \pm 0.04$ & $6.46 \pm 0.03$ & $6.42 \pm 0.03$ & $6.55 \pm 0.03$ \\
\hline & 6 & $6.62 \pm 0.03$ & $6.66 \pm 0.04$ & $6.64 \pm 0.03$ & $6.73 \pm 0.03$ \\
\hline \multirow[t]{4}{*}{ NH3-N (mg / $100 \mathrm{ml})$} & 0 & $16.75 \pm 0.80$ & $17.09 \pm 0.27$ & $16.98 \pm 0.70$ & $17.30 \pm 1.22$ \\
\hline & 2 & $26.15 \pm 0.91$ & $27.10 \pm 0.81$ & $27.10 \pm 1.21$ & $28.70 \pm 1.12$ \\
\hline & 4 & $27 \cdot 30 \pm 0.43$ & $29.11 \pm 0.85$ & $28.27 \pm 0.57$ & $29.86 \pm 0.46$ \\
\hline & 6 & $25 \cdot 30 \pm 1.40$ & $26.50 \pm 0.83$ & $26.03 \pm 0.42$ & $27.33 \pm 0.41$ \\
\hline Total VFA's (meq / $100 \mathrm{ml}$ ) & 4 & $11.92 \pm 0.32^{\mathrm{b}}$ & $13.11 \pm 0.32^{\mathrm{a}}$ & $13.00 \pm 0.34^{\mathrm{a}}$ & $11.5 \pm 0.31^{\mathrm{b}}$ \\
\hline Microbial protein $(\mathrm{g} / 100 \mathrm{ml})$ & 4 & $0.395 \pm 0.01^{b}$ & $0.525 \pm 0.02^{\mathrm{a}}$ & $0.513 \pm 0.01^{\mathrm{a}}$ & $0.492 \pm 0.01^{\mathrm{a}}$ \\
\hline
\end{tabular}

$\mathrm{a}-\mathrm{b}$ : Means in the same row followed by different letters differ significantly at $(\mathrm{P}<0.05)$.

Rumen TVF's concentrations were high $(\mathrm{P}<0.05)$ in the rumen of rams fed mixture forages ( $\mathrm{G} 2$ and G3) compared to other rations $\left(\mathrm{G}_{1}\right.$ and $\left.\mathrm{G}_{4}\right)$. Whereas, microbial protein was significantly higher in the rumen of sheep fed berseem $\left(\mathrm{G}_{4}\right)$ and their mixture $\left(G_{2}\right.$ and $\left.G_{3}\right)$ than that fed triticale alone $\left(\mathrm{G}_{1}\right)$ and the highest values were recorded with the mixture forages contained 50 and $70 \%$ Table 3 . Similar results were recorded by Soliman et al. (1997) with legume (Sesbania) and grass (Teosinte) and their mixtures, El-Kholany (2004) and Ibrahim et al. (2012) with using of mixture forage (or silage) in goats and sheep rations.

\section{Digestion coefficients and feeding values}

The digestibility of most nutrients Table 4 was higher with mixture forages ( $\mathrm{G}_{2}$ and $\left.\mathrm{G}_{3}\right)$ than the other rations $\left(\mathrm{G} 1\right.$ and $\left.\mathrm{G}_{4}\right)$. The digestion coefficients of $\mathrm{OM}, \mathrm{CF}$ and NFE were significantly higher with sheep fed $\mathrm{G}_{2}$ (50\% triticale - $50 \%$ berseem) and $\mathrm{G}_{3}$ (70\% triticale - 30\% berseem) than that fed $\mathrm{G}_{1}$ (triticale) and $\mathrm{G}_{4}$ (berseem).

Table 4. Digestion coefficients and nutritive values of the experimental rations fed to Rahmani sheep.

\begin{tabular}{|c|c|c|c|c|}
\hline \multirow{2}{*}{ Parameters } & \multicolumn{4}{|l|}{ Groups } \\
\hline & $\mathbf{G}_{1}$ & $\mathbf{G}_{2}$ & $\mathbf{G}_{3}$ & $\mathbf{G}_{4}$ \\
\hline \multicolumn{5}{|c|}{ Digestion coefficients } \\
\hline DM & $67.70 \pm 0.22^{c}$ & $72.04 \pm 0.42^{\mathrm{a}}$ & $71.40 \pm 0.35^{\mathrm{ab}}$ & $70.36 \pm 0.42^{b}$ \\
\hline $\mathrm{OM}$ & $71.37 \pm 0.45^{c}$ & $74.90 \pm 0.3^{\mathrm{a}}$ & $74.25 \pm 0.22^{\mathrm{a}}$ & $72.76 \pm 0.51^{b}$ \\
\hline $\mathrm{CF}$ & $65.12 \pm 0.65^{b}$ & $67.66 \pm 0.21^{\mathrm{a}}$ & $67.24 \pm 0.26^{a}$ & $65.35 \pm 0.26^{b}$ \\
\hline $\mathrm{CP}$ & $71.93 \pm 1.05^{\mathrm{b}}$ & $77.83 \pm 0.33^{\mathrm{a}}$ & $76.91 \pm 0.06^{\mathrm{a}}$ & $77.90 \pm 0.80^{\mathrm{a}}$ \\
\hline $\mathrm{EE}$ & $75.53 \pm 0.31^{\mathrm{a}}$ & $76.70 \pm 0.60^{\mathrm{a}}$ & $76.36 \pm 0.12^{\mathrm{a}}$ & $74.03 \pm 0.37^{b}$ \\
\hline NFE & $75.20 \pm 0.24^{b}$ & $78.65 \pm 0.51^{\mathrm{a}}$ & $78.03 \pm 0.24^{a}$ & $75 \cdot 75 \pm 0.60^{b}$ \\
\hline \multicolumn{5}{|c|}{ Nutritive values } \\
\hline TDN & $67.20 \pm 0.42^{\mathrm{b}}$ & $70.45 \pm 0.37^{\mathrm{a}}$ & $70.36 \pm 0.20^{\mathrm{a}}$ & $67.65 \pm 0.48^{b}$ \\
\hline DCP & $7.80 \pm 0.12^{\mathrm{b}}$ & $9.45^{ \pm 0.04^{b}}$ & $8.93 \pm 0.01^{\mathrm{c}}$ & $10.75 \pm 0.11^{\mathrm{a}}$ \\
\hline
\end{tabular}

a-b: Means in the same row followed by different letters differ significantly at $(\mathrm{P}<0.05)$. 
The DM, OM and CP digestibility's were significantly decreased with G1 (triticale) compared with G4 (berseem). But, the differences in CF and NFE digestibility values between triticale and berseem were not significant. Moreover, it was noticed that the higher value of CP digestibility was with $\mathrm{G}_{4}(77.90 \%)$ followed by $\mathrm{G}_{2}(77.83 \%)$ then $\mathrm{G}_{3}(76.91 \%)$ and finally $\mathrm{G}_{1}$ (71.93\%). Therefore, DCP was recorded the highest value $(\mathrm{P}<0.05)$ with $\mathrm{G}_{4}(10.75)$ while the lowest value was recorded with $G_{1}$ (7.80). Whereas, the TDN was significantly higher with sheep fed mixture forage $\left(G_{2}\right.$ and $\left.G_{3}\right)$ than those fed triticale $\left(G_{1}\right)$ or berseem $\left(G_{4}\right)$ forage alone.

The improvement in digestion coefficients of most nutrients and nutritive value (TDN) with mixture forage may be due to the positive effect between the two forages and the better condition of the rumen fermentation. The average TDN of the treatments in this study were in agreement with those mentioned by Ibrahim et al. (1978), Gabra (1984) and Soliman et al. (1997) with mixture forages (legume with grass). Moreover, Gabra and Sherif (1985) observed that DCP was higher with increasing berseem in sheep rations and the lowest value was recorded with triticale forage alone as reported in the study.

\section{Blood parameters}

The results in Table 5 indicated that all measured blood constituents of goats (protein, albumin, globulin, urea-N, glucose and creatinine) were not significantly affected by inclusion of triticale in tested diets indicating no adverse effects either on blood components or animal health, in general, that could occur as a result of such treatment.

Generally, the obtained results indicated that blood components measured showed alight differences due to the source of forages, while all levels were within the normal ranges which had been reported by Kaneko (1989) for healthy goats and on line with the finding of Haggag et al. (2002) who used triticale and berseem forage and their mixture in small ruminants rations.

\section{Milk production and its quality}

Data presented in Table 6 show the effect of the tested rations on average milk yield and its composition and milk quality as well. The obtained results indicated that average daily milk yield of Zaraibi goats was significantly higher with $\mathrm{G}_{2}$ compared with $\mathrm{G}_{1}$. The highest yield (1.350 kg) was recorded with $G_{2}$, followed by $(1.230 \mathrm{~kg})$ and the differences were significant as shown in Table 6.

The superiority of productive performance for lactating goats with mixtures forages, especially $\mathrm{G}_{2}$, may be due to positive associative effect between the two forages and the better condition of rumen fermentation as reported by Soliman et al. (1997), Ahmed et al. (2001 and 2013) and Ibrahim et al. (2012) as well as blood profile as reported in the present study. El-Kholany (2004) found that milk yield was significantly higher by lactating goats fed silage mixture $(50 \%$ maize$50 \%$ Sesbania) than that fed maize or Sesbania silage alone.

Table 5. Effect of feeding experimental rations on some blood serum parameters.

\begin{tabular}{lllll}
\hline \multirow{2}{*}{ Parameters } & \multicolumn{3}{l}{ Groups } & \\
\cline { 2 - 5 } & $\mathbf{G}_{\mathbf{1}}$ & $\mathbf{G}_{\mathbf{2}}$ & $\mathbf{G}_{\mathbf{3}}$ & $\mathbf{G}_{\mathbf{4}}$ \\
\hline Total protein (g/100ml) & $6.45 \pm 0.07$ & $6.43 \pm 0.08$ & $6.41 \pm 0.02$ & $6.57 \pm 0.06$ \\
Albumin (A) (g/100 ml) & $3.62 \pm 0.06$ & $3.61 \pm 0.06$ & $3.50 \pm 0.35$ & $3.58 \pm 0.03$ \\
Globulin (G) (g/100 ml) & $2.83 \pm 0.10$ & $2.82 \pm 0.02$ & $2.91 \pm 0.07$ & $2.99 \pm 0.03$ \\
A/G ratio & $1.28 \pm 0.06$ & $1.27 \pm 0.02$ & $1.20 \pm 0.05$ & $1.20 \pm 0.02$ \\
Urea-N (mg/100 ml) & $17.75 \pm 0.80$ & $18.40 \pm 0.50$ & $18.22 \pm 0.82$ & $19.10 \pm 0.69$ \\
Glucose (mg/100 ml) & $60.12 \pm 1.75$ & $62.00 \pm 1.13$ & $60.63 \pm 1.80$ & $59.97 \pm 1.43$ \\
Creatinine (mg/10oml) & $1.40 \pm 0.05$ & $1.42 \pm 0.03$ & $1.52 \pm 0.06$ & $1.50 \pm 0.04$ \\
\hline
\end{tabular}


Table 6. Effect of feeding experimental rations on milk production and its quality of dairy Zaraibi goats.

\begin{tabular}{lllll}
\hline Parameters & Groups & & \\
\cline { 2 - 4 } & $\mathbf{G}_{\mathbf{1}}$ & $\mathbf{G}_{\mathbf{2}}$ & $\mathbf{G}_{\mathbf{3}}$ & $\mathbf{G}_{\mathbf{4}}$ \\
\hline $\begin{array}{l}\text { Average milk yield (k/h) } \\
\text { Milk composition }\end{array}$ & $1.230 \pm 0.01^{\mathrm{b}}$ & $1.35 \mathrm{O} \pm 0.02^{\mathrm{a}}$ & $1.310 \pm 0.02^{\mathrm{ab}}$ & $1.260 \pm 0.02^{\mathrm{ab}}$ \\
Fat (\%) & $4.05 \pm 0.04^{\mathrm{a}}$ & $4.21 \pm 0.03^{\mathrm{a}}$ & $4.20 \pm 0.03^{\mathrm{a}}$ & $3.97 \pm 0.05^{\mathrm{b}}$ \\
Protein (\%) & $3.00 \pm 0.03$ & $3.06 \pm 0.03$ & $3.01 \pm 0.03$ & $3.03 \pm 0.03$ \\
Lactose (\%) & $4.58 \pm 0.03$ & $4.47 \pm 0.02$ & $4.45 \pm 0.02$ & $4.59 \pm 0.03$ \\
Total solids (\%) & $12.34 \pm 0.09$ & $12.46 \pm 0.07$ & $12.38 \pm 0.09$ & $12.31 \pm 0.08$ \\
SNF (\%) & $8.29 \pm 0.04$ & $8.25 \pm 0.04$ & $8.18 \pm 0.04$ & $8.34 \pm 0.04$ \\
Ash (\%) & $0.71 \pm 0.04$ & $0.72 \pm 0.003$ & $0.72 \pm 0.004$ & $0.72 \pm 0.004$ \\
Somatic cell count, (SCC) $\times 10^{3}$ & $478 \pm 7.98^{\mathrm{b}}$ & $443 \pm 5.93^{\mathrm{c}}$ & $469 \pm 7.94^{\mathrm{b}}$ & $489 \pm 8.25^{\mathrm{a}}$ \\
pH value & $6.67 \pm 0.03$ & $6.62 \pm 0.02$ & $6.63 \pm 0.02$ & $6.66 \pm 0.02$ \\
Acidity (\%) & $0.16 \pm 0.002$ & $0.16 \pm 0.002$ & $0.16 \pm 0.002$ & $0.17 \pm 0.003$ \\
\hline
\end{tabular}

a-b-c: Means in the same row followed by different letters differ significantly at $(\mathrm{P}<0.05)$.

Milk fat percentage was significantly $(\mathrm{P}<0.05)$ lower with $\mathrm{G}_{4}$ (3.97) compared with the others as shown in Table 6. The positive effect of triticale forage and their mixture with berseem on milk fat \% may be due to the clear increase in ether extract (EE) digestibility and high content of $\mathrm{EE}$ in triticale forage. But the effect of the tested experimental rations on other milk contents (protein, lactose, total solids, solids non fat and ash) were not significant $(\mathrm{P}<0.05)$ and the obtained values of milk constituents were within the normal range given by Ahmed (1999), El-Kholany (2004) and Ibrahim et al (2012) for Zaraibi goat.

Somatic cell count (SCC) was significantly affected by the tested experimental rations (Table,6). The highest value (489000) of SCC was recorded with $\mathrm{G}_{4}$, followed by $G_{1}$ (478000), then $G_{3}$ (469000) and lastly. The lowest value (44300o) was recorded with $\mathrm{G}_{2}$ and the differences were significant. It is interesting to not a negative relationship between SCC and milk yield. In this respect, Baro et al. (1994), Bedo et al. (1995) and Ahmed et al. (2008a) found that SCC correlated negatively with milk yield, But, the differences in same milk quality such as $\mathrm{pH}$ value and acidity among the different tested groups were not significant and the obtained values were within the normal ranges given by Shehata et al. (2006), Ahmed et al. (2008b) and Maged et al. (2017).

\section{Economic efficiency}

Data of average feed intake and average milk yield during the experimental period as well as feed conversion efficiency of the dairy Zaraibi goats are summarized in Table 7.

Table 7. Feed and economic efficiency for lactating Zaraibi goats fed different experimental rations.

\begin{tabular}{lllll}
\hline \multirow{2}{*}{ Items } & Groups & & G3 & G4 \\
\cline { 2 - 5 } & G1 & G2 & 665 & 640 \\
Daily feed intake (g/h) & & & 755 & 680 \\
CFM (g/h/d) & 650 & 660 & 1420 & 1320 \\
Forage & 720 & 765 & 4.06 & 3.77 \\
Total DM intake (g/h) & 1370 & 1425 & 98.75 & 91.79 \\
DM intake (g/kg BW) & 3.91 & 4.07 & 184.0 & 187.0 \\
DM intake (g/kg w 0.75) & 95.27 & 99.10 & 1310 & 1260 \\
CP intake (g/h/d) & 172.0 & 189.0 & & \\
Average milk yield (g/h/d) & 1230 & 1350 & 0.08 & 1.05 \\
Feed conversion efficiency & & & & 0.148 \\
Kg DM / kg milk & 1.11 & 1.01 & 2.58 & \\
Kg CP/ kg milk & 0.139 & 0.140 & 4.59 & 2.50 \\
Economic efficiency & & & 1.97 & 4.41 \\
Cost of consumed (L. E./h) & 2.48 & 2.57 & 1.98 \\
Price of milk produced (L.E./L) & 4.31 & 4.73 & 1.90 & 1.76 \\
Feed cost / kg milk. L.E. & 2.02 & 1.84 & \\
Economic efficiency (\%) & 1.74 &
\end{tabular}

${ }^{*}$ The prevailing prices / ton at time of study are 3600 L.E., berseem forage cost 300L.E., triticale 200 L.E., and 1 ton of berseem forage/ triticale forage cost 250 L.E., while $1 \mathrm{~kg}$ milk 3.5 L.E. 
The data indicated that the average milk yield recorded the highest value $(1.350 \mathrm{~kg} / \mathrm{h} / \mathrm{d})$ with $\mathrm{G}_{2}$ followed by $\mathrm{G}_{3}(1.31 \mathrm{~kg} / \mathrm{h} / \mathrm{d})$ and $(1.260 \mathrm{~kg} / \mathrm{h} / \mathrm{d})$ with $\mathrm{G}_{4}$ and lastly $\mathrm{G}_{1}$ which recorded the lowest value $(1.230 \mathrm{~kg} / \mathrm{h} / \mathrm{d})$, and the differences were significant. Thus, the feed conversion calculated as DM and CP (intake / milk yield) was better in $\mathrm{G}_{2}$ (1.01 and 0.140 , respectively) and $\mathrm{G}_{3}$ (1.08 and 0.140 , respectively) compared with $\mathrm{G}_{1}$ (1.11 and o.139, respectively). Similar results were observed by El-Kholany (2004) and Ahmed (2013) using mixture of silages for Zaraibi goats. However, the obtained values of feed conversion are within the normal range given by Gabr et al. (1999). In the other study, Shehata et al. (2006) found that the feed conversion efficiency of Zaraibi goats ranged from 1.17 to $1.28 \mathrm{~kg}$ milk / kg DM intake.

Data in Table 7 indicated that the highest total feed cost (LE/h) along the feeding period was observed for $\mathrm{G}_{3}$ (2.58) compared with other groups (2.57, 2.50 and 2.48 for $G_{2}, G_{4}$ and $G_{1}$, respectively). Therefore, the highest total feed cost / kg milk (LE) was observed for $G_{1}$ (2.02) and the lowest values were for $G_{2}, G_{3}$ and $G_{4}(1.90,1.97$ and 1.98, respectively), due to the highest daily milk yield as well as the lowest of feed consumption in the two groups (forage mixture).

\section{Conclusion}

It could be concluded that using mixture forage (triticale with berseem) in feeding Zaraibi goats had a positive effect on improving the feeding value, milk yield, and milk composition as well as feed utilization efficiency. Moreover, no remarkable any adverse of feed triticale on blood or rumen parameters and digestion coefficient. So, Triticale forage could be suitable for feeding goats as it is or as a mixture with berseem.

\section{Conflict of interest statement}

Authors declare that they have no conflict of interest.

\section{References}

A.O. A. C., 1995. Official Methods of Analysis. (16th) Edt. Association Analytical Chemists, Washington, D.C., USA.

Abdel-Galil, M. M.., Soliman, E. S., 2002. Triticale as multi cut crop for forage and grain. J. Agric. Sci. Mansoura Univ. 27, 61-69.

Ahmed, M.E., Shehata, E.I., El-Kholany, M. E., ElEmam, G.I., Khalifa, E.I., Bahery, H., 2013. Productive performance of Zaraibi goats fed berseem and/or triticale silage. The $4^{\text {th }}$ Scientific Conference of Animal Production Research Institute, 184: 192.

Ahmed, M. E., Shehata, E. I., Ibrahim, F. A., Aiad, K. M., El-Zalaky, O. A., 2008a. Milk production and quality of dairy Zaraibi goats fed Trifolium alexandarinum (1st cut) silage with some crop residues. Egypt. J. Sheep Goat Sci. 3(2), 27-40.

Ahmed, M. E., Shehata, E. I., Abou Ammou, F. F., Abdel- Gwad, A.M., Aiad, K. M., 2008b. Milk production, feed conversion rate and Zaraibi goat in response to bacterial feed additive during late pregnancy and lactation. Egypt. J. Anim. Prod. 45, 189-203.

Ahmed, M. E., Abdelhamid, A.M., Abou Ammou, F.F., Soliman, E.S., El-Kholy, N.M., Shehata, E.I., 2001. Response of milk production of Zaraibi goats to feeding silage containing different levels of teosinte and kochia. Egypt. J. Nutr. Feeds. 4 (Special Issue), 141.

Ahmed, M.E., 1999. Improving feed conversion efficiency during reproduction-stress-phases. Ph.D. Thesis Fac. Agric., Mansoura Univ.

Barnett, A.J.G., Abd El-Tawab, G., 1957. Determination of lactose in milk and cheese. J. Sci. Food Agric. 8, 437-441.

Baro, J. A., Carriedo, J. A., San Primitivo, F., 1994. Genetic parameters of test day measures for somatic cell count, milk yield and protein percentage of milking ewes. J. Dairy Sci. 77, 2658.

Bedo, S., Nikodemusz, E., Gundel, K., 1995. Variations in the yield, composition and somatic cell count of ewes' milk during lactation. Act. Vet. Hung. 43, 463.

Conway, E. F., 1957. Micro diffusion Analysis and Volumetric Error. Rev. Ed. Lock Wood, London.

Duncan, D., 1955. Multiple ranges and multiple Ftest. Biometrics. 11, 1.

El-Kholany, M. M., 2004. Evaluation of some new green fodder for Farm animals. Ph.D. Thesis Fac. of Agric., Mansoura Univ., Egypt.

Gabr A.A., Mehrez, A.Z., Soliman, E.S.M., ElKholany, M., 1999. Response of lactating goats to diets containing reed grass (Aroundo donax L.) versus sorghum plants. Egypt. J. Nutr. 
Feeds. 2 (Special Issue), 297.

Gabra, M. A., 1984. Studies on the productivity and feeding qualities of some annual and perennial forages as affected by some agronomic practices fed to sheep in metabolism trials including nutritional balances. Ph.D., thesis, Faculty of Agric., Cairo Univ., Egypt.

Gabra, M. A., Sherif, S. W., 1985. The feeding value nitrogen balance and daily intake of triticale, berseem and there mixture in metabolism trials with sheep. Annu. Agric. Sci. Moshtohor. 23, 683-693.

Garcia Del Moral, L.F., 1992. Leaf area, grain yield and yield components following forage removal in triticale. J. Agron. Crop Sci. 168, 100-107.

Haggag, M.El-H., Soliman, E. S., Ahmed, M.E., 2002. Triticale forage as a feed for sheep. Proc. $1^{\text {st }}$ Ann. Sc. Conf. Animmal and Fish Prod., Mansoura, Sep. P: 77.

Hill, G.M., Utley, P.R., 1989. Digestibility, protein metabolism and ruminal degradation of Beagle 82 triticale and Kline barley fed in corn-based cattle diets. J. Anim. Sci. 67(7), 1793-1804.

Ibrahim, F.A., Soliman, E.S, Abd El-Hamid, A. A., Ahmed, M. E., 2012. Growth performance and feed utilization efficiency of Rahmani lambs fed some legume and /or grass silages. Egypt. J. Sheep Goats Sci. 7(2), 1-10.

Ibrahim, S.A., Abou-Raya, A.K., Makky, A. M., ElSamman, S., 1978. The effect of inter seeding Italian ray grass (IRG) with clover on the composition digestibility and feeding value of the green herbage with reference to nitrogen balance. Agric. Res. Rev. Cairo. 56, 135-143.

Kaneko, J. J., 1989. Clinical Biochemistry of Animals. $4^{\text {th }}$ Edn., Academic Press, Inc. USA.

Ling, E. R., 1963. A Text Book of Dairy Chemistry. 3rd Edn. Chapman and Hall Ltd., London.

Maged, G.A., El-Kholany, M.E., Aboul-Omran, M.A., Al-Mowafy, A.A., 2017. Response of milk production of dairy Zaraibi goats to feeding rations containing different levels of sesame seeds unsuitable for manufacturing as an inexpensive and untraditional source of protein. J. Anim. Poult. Prod. Mansoura Univ. $8(3), 49-54$.

NRC, 1981. Nutrient Requirements of Domestic Animals. Nutrient Requirements of Goats. National Research Council, Washington, D.C. USA, of Official Analytical Chemists, Washington, D.C., USA.

SAS, 2003. SAS. ISTATR User Guid: Statistics. Ver. 9.1; Fourth Edition, SAS Institute Inc., Cary, Nc.

Shehata, E.I., Ahmed, M.E., Abdelhamid, A.M., Abou Ammou, F.F., Haggag, M. El-H., 2001. Comparative nutritive values of silage ration containing different level of teosinte and Kochia. Egypt. J. Nutr. Feeds. 4, 129-140.

Shehata, E.I., Ahmed, M.E., Abou Ammou, F.F., Soliman, A.A.M., Aiad, K.M., Abdel-Gawad, A. M., 2006. Comparison of feeding reed as hay or silage with feeding berseem hay or maize silage to dairy Zaraibi goats. Egypt. J. Sheep Goat Desert Anim. Sci. 1, 233-247.

Shultz, T.A., Shultz, E., 1970. Estimation of rumen microbial nitrogen by three analytical methods. J. Dairy Sci. 53(6), 781-784.

Soliman, E.S., Kinizy, A.E.M., Mohamed, B. K., Haggag, M. El-H., 1997. Studies on using sesbania and teosinte forage in feeding of growing Zaraibi goats Egypt. J. Appl. Sci. 12(5), 36.

Varughese, G.T., Parker, S., Soari, E., 1987. Triticale CIMMYT, Mixico.

Warner, A.C.I., 1964. Production of volatile fatty acids in the rumen, methods of measurements. Nutr. Abst. Rev. 34, 339-352.

Zaid, A. M., Shehata, E. I., Ahmed, M. E., Abd elGawad, A.M., 2009. Growth performance of male Zaraibi goats fed teosinte forage in rations differing in roughage: concentrate ratio. $\mathrm{J}$. Agric. Sci. Mansoura Univ. 34(11), 10441.

Zobell, D.R, Goon Ewardene, L. A., Engstrom, D.F., 1992. Use of triticale silage in diets for growing steers. Can. J. Anim. Sci. 72, 181- 184.

\section{How to cite this article:}

El-Kholany, M. E., Sadek, W.M.A., Aboul-Omran, M. A., Behery, H. R., El-Emam, G.I., El-Sawah, T.H., Mehany, A. A., Al-Mwafy, A., 2019. Response of lactating Zaraibi goats fed with berseem and/or triticale forage on milk production, feed utilization and economic efficiency. Int. J. Curr. Res. Biosci. Plant Biol. 6(3), 1-8. doi: https://doi.org/10.20546/ijcrbp.2019.603.001 